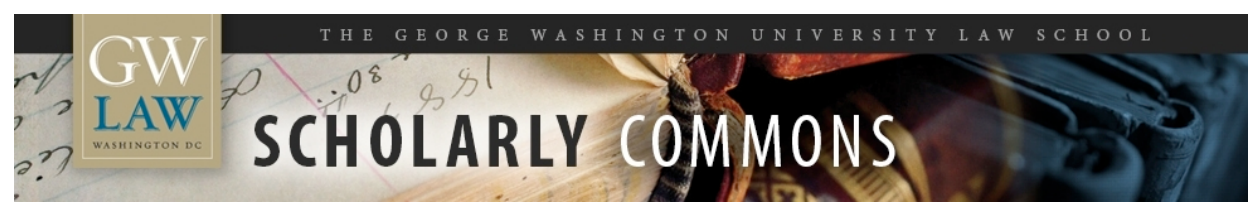

\title{
The International Legality of U.S. Military Cross-Border Operations from Afghanistan into Pakistan
}

\author{
Sean D. Murphy \\ George Washington University Law School, smurphy@law.gwu.edu
}

Follow this and additional works at: https://scholarship.law.gwu.edu/faculty_publications

Part of the Law Commons

\section{Recommended Citation}

Sean D. Murphy, The International Legality of U.S. Military Cross-Border Operations from Afghanistan into Pakistan, 84 Int'l Legal Stud. (2008).

This Article is brought to you for free and open access by the Faculty Scholarship at Scholarly Commons. It has been accepted for inclusion in GW Law Faculty Publications \& Other Works by an authorized administrator of Scholarly Commons. For more information, please contact spagel@law.gwu.edu. 
Draft October 27, 2008

\title{
The International Legality of U.S. Military Cross-Border Operations from Afghanistan into Pakistan
}

\author{
Sean D. Murphy* \\ I. Introduction
}

An aspect of U.S. military involvement in Afghanistan since 2001 has been the conduct of cross-border U.S. operations from Afghanistan into Pakistan, undertaken for the purposes of striking at the camps, compounds, and convoys of Al Qaeda and Taliban elements based in Pakistan, and of defending against cross-border attacks and infiltration by those militants from Pakistan into Afghanistan. As a matter of scale, U.S. cross-border operations are far less momentous than operations that seek to topple a de jure government (as occurred when the United States intervened in Iraq in 2003, ousting the government of Saddam Hussein) or a de facto government (as occurred when the United States intervened in Afghanistan in 2001, displacing the largely-unrecognized government of the Taliban). Nevertheless, these smallerscale cross-border attacks on non-state actors, though they entail less intrusive and more temporary projections of force, implicate important issues of sovereignty, stability, and selfdefense, and raise difficult questions about the role of law in regulating low intensity conflict.

\footnotetext{
* Patricia Roberts Harris Research Professor of Law, George Washington University Law School. My thanks to Polly Nayak and Jon Shaub for extremely insightful comments on the complicated circumstances of Afghan-Pakistani relations, and to Erin Creegan for superb research assistance. All mistakes, of course, are my own.
} 
This essay discusses the nature of these cross-border operations for the purpose of assessing their legality under the jus ad bellum, meaning their consistency with the norms embodied in Articles 2(4) and 51 of the U.N. Charter. Attention is devoted to unpacking the complicated and evolving circumstances on the ground, but the facts at issue in many instances are quite difficult to discern, and hence can support only tentative legal conclusions. While the focus here will principally be on U.S. operations from Afghanistan into Pakistan from 2002 to the present, the analysis is relevant in other contexts as well, such as Turkey's cross-border operations in northern Iraq against Kurdistan Workers' Party (PKK) or Colombia's recent forays into Ecuador against the Revolution Armed Forces of Colombia (FARC).

Among other things, this essay assumes that analyzing the jus ad bellum legality of U.S. cross-border operations into Pakistan is important to the United States. U.S. law and policy, of course, generally call for compliance with international law in the conduct of U.S. military operations. Further, the United States' ability to secure the cooperation of other states may turn on whether U.S. operations are in compliance with international law. Support from U.S. allies includes support from Pakistan itself, in that most cargo and much fuel supporting the approximately thirty thousand U.S. forces that are based in land-locked Afghanistan transit through Pakistan. ${ }^{1}$ Indeed, in September 2008, the Pakistani government threatened to close down U.S. supply routes into Afghanistan in response to U.S. cross-border operations, prompting

${ }^{1}$ See Congressional Research Service, Pakistan-U.S. Relations 24 (Aug. 25, 2008), at http://www.fas.org/sgp/crs/row/RL33498.pdf [hereinafter "CRS Report"]; Ann Scott Tyson, Gates Is Pessimistic On Pakistani Support, WASH. Post, Sept. 24, 2008, at A16 (reporting comments of Senators Carl Levin and John Warner). 
the United States to rethink its strategy in this area. ${ }^{2}$ Broader U.S. objectives of maintaining a stable Pakistan-an objective arguably paramount for the United States in combating terrorism ${ }^{3}$ - may turn in part on internal Pakistani perceptions concerning the legality of U.S. conduct. Moreover, though adjudication of the legality of U.S. cross-border operations before an inter-state tribunal, such as the International Court of Justice, may not be likely, it is not impossible, and adverse rulings may affect the ability of the United States to maintain both domestic and international support for its policies. ${ }^{4}$ Finally, the states parties to the Rome Statute ${ }^{5}$ establishing the International Criminal Court, at their review conference in 2010, may activate the ICC's jurisdiction over the crime of aggression, thereby potentially exposing U.S. military personnel engaged in such cross-border operations to international criminal liability. ${ }^{6}$ For all these reasons, there is value in assessing the legality of U.S. cross-border operations against Pakistan under the jus ad bellum.

II. U.S. Cross-Border Operations from Afghanistan to Pakistan

${ }^{2}$ See Sean D. Naylor, Spec Ops Raids Into Pakistan Halted, NAVy TimES, Sept. 29, 2008.

${ }^{3}$ See Polly Nayak, The Impact of Pakistan's and Bangladesh's National Strategies on U.S. Interests, in STRATEGIC ASIA 2008-09: ChALLENGES AND ChOICES 297, 318-20 (Ashley J. Tellis, Merch Kuo \& Andrew Marble eds., 2008).

${ }^{4}$ For instance, Pakistan might invoke against the United States the 1959 bilateral Treaty of Friendship and Commerce, U.S.-Pak., Nov. 12, 1959, 12 U.S.T. 110, which provides for International Court of Justice jurisdiction when disputes arise. Iran and Nicaragua have both invoked similar treaties against the United States in response to U.S. military or paramilitary operations.

${ }^{5}$ See Rome Statute of the International Criminal Court, July 17, 1998, 2187 U.N.T.S. 3.

${ }^{6}$ The exact mechanism for applying the crime of aggression in a given circumstance is not yet known, though ICC jurisdiction might be triggered based on decision-making at the ICC itself (without affirmative action at Security Council) in circumstances where the alleged aggression is undertaken from or against a party to the Rome Statute. At present, Afghanistan is a party to the Rome Statute, while the United States and Pakistan are not. See International 


\section{A. The Afghan-Pakistan Border in Law}

The 2,250 kilometer-long border between Afghanistan and Pakistan was essentially established in 1893 by Sir Henry Mortimer Durand, a civil servant and diplomat of colonial British India. The purpose of the line (which became known as the "Durand line") was to delimit British colonial holdings in India from Afghanistan, since Pakistan did not yet exist as a nation state. The standard account is that the Durand line was negotiated with and accepted by the Amir of Afghanistan, Abdur Rahman Khan, and when Pakistan achieved national independence in 1947, Pakistan succeeded to that border. ${ }^{7}$

The border, however, is not without some controversy. Given that the border divides the ancestral home of the Pashtun people, the Pashtuns have objected that the border was imposed by a strong colonial power (Britain) upon a weak state (Afghanistan), which was in no real position to object. In the years after Pakistani independence, Afghanistan began to voice a view that the Durand line lapsed with the end of the British colonial rule, ${ }^{8}$ a position that essentially rejects the internationally-accepted principle of uti possedetis juris (which maintains that states newly formed our of colonies should have the same borders that they had before their independence).

Criminal Court, Assembly of States Parties, http://www.icc-cpi.int/asp/statesparties.html.

7 See Percy Sykes, Sir Mortimer Durand 200-217 (1956); MARTIN EWANS, AFGHANistan: A NEW History 106-107 (2002).

${ }^{8}$ See Owen Bennett Jones, PAKistan: Eye of the Storm 137 (2003) ("Ever since partition, Kabul has argued that the Durand Line was never meant to be an international boundary and has complained that it deprived Afghanistan of territory that had been historically under its control."). 
The Afghan position is widely accepted within Afghanistan, but has gained no traction in the international community, and would likely not be accepted by any authoritative decision-makers, such as the International Court of Justice. By contrast, Pakistan has maintained that the border is of longstanding legality, is fully demarcated, and largely follows a series of topographic features that provides for a natural divide. ${ }^{9}$

In short, the border as a legal construct is well known and accepted within the international community. As such, arguments in favor significant cross-border operations cannot credibly justified on grounds of uncertainty as to the location of the border or genuinely disputed territory; other justifications are necessary.

\section{B. The Afghan-Pakistan Border in Practice}

While the location of the Afghan-Pakistan border is relatively well settled, the functioning of that border as an effective barrier between the two states is far less so. The movement of peoples across the border is generally unchecked, with sizable populations of both Pashtuns and Baluch on both sides of the border moving freely and engaged in extensive

${ }^{9}$ For a more detailed discussion of these points and the history of the border, see Barnett R. Rubin \& Abubakar Siddique, Resolving the Pakistan-Afghanistan Stalemate, U.S. Institute of Peace Spec. Rep. 176 (Oct. 2006). 


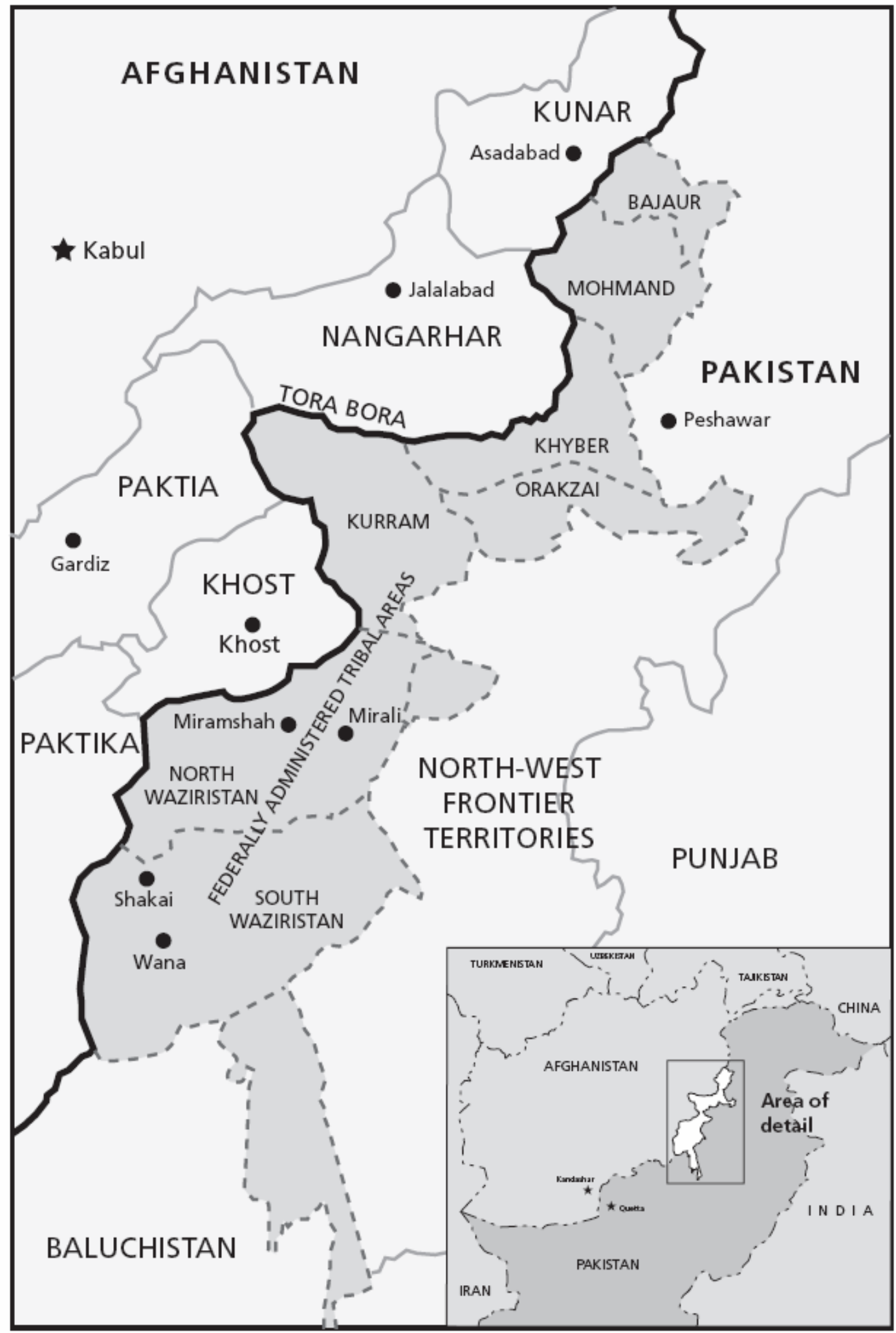

RAND MG595-4. 2

area. 
smuggling operations that pre-date $2001{ }^{10}$ The graphic ${ }^{11}$ depicts the border area. On the Pakistani side of the border, there are certain groups that are the object of U.S. cross-border operations.

First, there are the remnants of Al Qaeda and other extremist Islamic "foreign fighters" who fled across the border from Afghanistan after the U.S.-led intervention in the fall of 2001. U.S. defense officials and independent analysts place the number of Al Qaeda fighters in Afghanistan at somewhere between 150 and 500 persons. ${ }^{12}$ Osama Bin Laden is thought to be hiding among those fighters in the Waziristan region of Pakistan, which is part of the Federally Administered Tribal Areas (FATA) immediately adjacent to the border, ${ }^{13}$ but his whereabouts are not confirmed.

Second, there are remains of the Afghan Taliban regime (a predominately Pashtun movement) that also fled into Pakistan in late 2001, but has reorganized and experienced

\footnotetext{
${ }^{10}$ See Rizwan Hussain, Pakistan And the EMERgEnCE OF ISLAmic Militancy in AFGHANISTAN 55-92 (2005).

11 The graphic appears in Seth Jones, Counterinsurgency in Afghanistan, RAND Counterinsurgency Study Vol. 4, at 45 (June 9, 2008) at http://www.rand.org/pubs/monographs/2008/RAND_MG595.pdf, and is reprinted with permission of RAND Corporation, Santa Monica, CA.

${ }^{12}$ See Eric Schmitt \& Mark Mazzetti, Pakistan's Planned Accord With Militants Alarms U.S., N.Y. TIMES, Apr. 30, 2008, at A10; see also CRS Report, supra note 1, at 20-21; Jones, supra note 11, at 43-44; National Intelligence Council, National Intelligence Estimate: The Terrorist Threat to the US Homeland 6 (July 2007), http://www.dni.gov/press_releases/20070717_release.pdf.

${ }^{13}$ U.S. cross-border operations at issue in this paper are focused on the FATA region, not the North West Frontier Province (NWFP) or Baluchistan. It should be noted, however, that Pakistani militants have also begun holding territory (and attacking Pakistani military and government targets) in certain areas of the NWFP.
} 
resurgence in fomenting guerilla resistance to the new Afghan government and its foreign supporters, including the United States. ${ }^{14}$ At present, Afghan insurgent groups based along the Afghan-Pakistani border straddle both sides of the border, engaging in classic guerrilla warfare by attacking targets in Afghanistan and then retreating to mountain strongholds on both sides of the border. ${ }^{15}$

Third, there is Pakistan's own Taliban movement (called Tehrik-e-Taliban Pakistan), led by Baitullah Mehsud, and consisting of a cluster of Pashtun tribes and clans united principally by a shared goal of resistance to the Pakistani and U.S. governments. Tehrik-e-Taliban Pakistan has established strongholds in North and South Waziristan, and at present there are concerns about "Talibanization" of the entire western region of Pakistan. While Pakistan's Taliban is principally focused on activities within Pakistan, it is also promoting fighting across the border with U.S. forces in Afghanistan. ${ }^{16}$

The relationship between Al Qaeda, other militant groups, the Afghan Taliban, and the Taliban in Pakistan is not entirely transparent, but connections clearly do exist. Many of the "foreign fighters" in the region take their guidance from senior Al Qaeda leaders and serve as

${ }^{14}$ See Jones, supra note 11, at 58-59 (“Afghan insurgents used Pakistan as a staging area for offensive operations. Taliban insurgents that operated in the southern Afghan provinces of Kandahar, Oruzgan, Helmand, and Zabol had significant support networks in such Pakistani provinces as Baluchistan and the Federally Administered Tribal Areas, including in Waziristan. . .. The Taliban conduct much of their financing and recruiting operations on the Pakistani side of the border.")

${ }^{15}$ See id. at 38, 50-51.

${ }^{16}$ CRS Report, supra note 1, at 18-20 \& 29. Some believe Baitullah Mehsud masterminded the assassination of former Pakistani Prime Minister Benazir Bhutto in December 
"trainers, shock troops, and surrogate leaders for Taliban units in the field." ${ }^{17}$ In this way, Al Qaeda is supporting militants who cross the border into Afghanistan, as well as insurgent groups in Afghanistan, in their attacks on U.S. and coalition forces, as well as the Afghan government. A recent RAND report states:

Al Qaeda played a critical role in the [Afghan] insurgency as a force multiplier, assisting insurgent groups such as the Taliban at the tactical, operational, and strategic levels. Groups such as the Taliban used support and training from jihadists to construct increasingly sophisticated [improvised explosive devices [IEDs]], including IEDs with remote-control detonators. For example, there were a handful of al Qaeda-run training facilities and IED assembly facilities in such places as North and South Waziristan. ... Al Qaeda received operational and financial support from local clerics and Taliban commanders in Waziristan. ${ }^{18}$

A Taliban commander characterized the Taliban and Al Qaeda in Pakistan as having "close ties," while a U.S. military intelligence official stated that "trying to separate Taliban and al Qaeda in Pakistan serves no purpose. It's like picking gray hairs out of your head."19

In recent testimony before the U.S. Senate Armed Service Committee, the vice chairman of the Joint Chiefs of Staff, General James Cartwright, testified that Islamic militant fighters crossing the border from the FATA region of Pakistan into Afghanistan account for about 30\% to $40 \%$ of the guerilla attacks taking place in Afghanistan against the Afghan government or its

2007. In early October, unconfirmed reports began circulating of Mehsud's death from illness.

${ }^{17}$ See Jones, supra note 11 , at 46.

${ }^{18} I d$. at 62-63.

${ }^{19}$ Quoted in Peter Bergen, Assessing the Fight Against Al Qaeda, Testimony before the House Permanent Select Committee on Intelligence, at 8 (Apr. 9, 2008), http://www.fas.org/irp/congress/2008_hr/040908bergen.pdf. 
allies. ${ }^{20}$ Further, those cross-border attacks (many of which are suicide attacks) from Afghanistan have been on the rise, from twenty a month in March 2007 to fifty-three a month in April 2008, with many attacks targeting troops from countries considering whether to withdraw their forces from Afghanistan, such as Canada and the Netherlands. ${ }^{21}$ According to the RAND study,

Several factors can be attributed to the rise in suicide attacks. First, the Taliban successfully tapped into the expertise and training of the broader jihadist community, especially al Qaeda. Jihadists imparted knowledge on suicide tactics to Afghan groups through the Internet and in face-to-face visits. With al Qaeda's assistance, these militants helped supply a steady stream of suicide bombers. Second, al Qaeda and the Taliban concluded that suicide bombing was more effective than other tactics in killing Afghan and coalition forces. ${ }^{22}$

The government of Pakistan generally does not control the FATA region, which is divided into largely autonomous provinces loosely linked to Islamabad by means of a "political agent" (a vestige of British colonialism). Indeed, the legal relationship is so attenuated that the ability of the Pakistani government, under Pakistani law, to authorize U.S. military actions in FATA is not entirely clear. Consequently, prior to the attacks of September 11, 2001, the border areas were almost entirely in the hands of local tribal groups. After 9/11 and the U.S.-led intervention in Afghanistan, the United States urged Pakistan's central government to exercise greater control over the border areas, which resulted in the Pakistani army reluctantly conducting

${ }^{20}$ See Ann Scott Tyson, Gates Is Pessimistic On Pakistani Support, WASH. Post, Sept. 24, 2008, at A16 (reporting testimony of General Cartwright); see also Jones, supra note 11, at 64-65 ("The use of suicide attacks was encouraged by al Qaeda leaders in Pakistan . . . . Suicide bombers included Afghans, Pakistanis, and some foreigners. Most suicide bombers through 2007came from Afghan refugee camps in Pakistan.").

${ }^{21}$ Jane Perlez, Pakistan Defies U.S. On Halting Attacks, N.Y. TIMES, May 16, 2008, at A6 (referring to NATO and U.S. sources); CRS Report, supra note 1, at 31.

${ }^{22}$ See Jones, supra note 11, at 65; see also Bergen, supra note 19, at 7 ("The use of suicide attacks, improvised explosive devices and the beheadings of hostages - all techniques that al Qaeda perfected in Iraq - are methods that the Taliban has increasingly adopted in 
some counter-terrorism operations in the FATA against Taliban and Al Qaeda operatives. Those operations were not effective in eliminating militant groups and caused significant collateral civilian casualties that inflamed local animosity toward the Pakistani government and army. ${ }^{23}$ Most military operations have been left to the 80,000-person "Frontier Corps," a poorly trained and underfunded paramilitary force consisting of recruits from local Pashtun tribes serving under regular Pakistani army officers. While these units have sometimes engaged in assaults on Taliban and Al Qaeda elements in the border areas, there are credible reports (denied by the Pakistani government) that elements of the Frontier Corps are closely aligned with the Taliban. ${ }^{24}$ In response to Pakistani government military operations, the militant groups in FATA began conducting a series of suicide attacks against various targets in other parts of Pakistan to show their strength and weaken the Pakistani government, though such attacks may have undermined support for the militants within the Pakistani population. ${ }^{25}$

Islamabad's efforts to “govern" FATA have always entailed deals being struck between the government, its regional authorities, or the Pakistani army and FATA tribal officials. In the post-9/11 period, the Pakistani government continued to pursue such deal-making, including agreements not just with tribal groups but with Tehrik-e-Taliban Pakistan itself, addressing

Afghanistan, making much of the south of the country a no-go area.").

${ }^{23}$ See Husain Haqqani, Pakistan: Between Mosque And Military 301-310 (2005);

CRS Report, supra note 1, at 26-27; Jones, supra note 11, at 59-60.

${ }^{24}$ See Jones, supra note 11, at 56 (finding that parts of the Pakistan government, especially members of the Inter Services Intelligence (ISI) Directorate and Frontier Corps, provide support to the Taliban in Pakistan); CRS Report, supra note 1, at 23; Anne Scott Tyson, Border Complicates War in Afghanistan, WASH. Post, Apr. 4, 2008, at A1 (quoting a frontline U.S. soldier as saying the "Frontier Corps might as well be Taliban. . . They are active facilitators of infiltration."). 
issues such as control of the border areas, militant terrorist attacks within Pakistan, and militant cross-border attacks into Afghanistan. ${ }^{26}$ As such, the strategy of the central Pakistani government in handling the western border areas has oscillated between military action and negotiation.

The opaqueness of the relationship between the Pakistani Army, the Frontier Corps, and the militants in FATA somewhat clouds the legal analysis that follows, since the cross-border militant attacks on Afghanistan might or might not be viewed as attributable to the Pakistani government, either due to that government's outright collusion with the Taliban or its failure to take the steps necessary to stop cross-border attacks. On the one hand, in some instances U.S. intelligence officials, as well as independent researchers, have concluded that the Pakistani government has provided direct support to militants for operations in Afghanistan, such as logistical support for a militant car bombing at the Indian Embassy in Kabul in July 2008, a charge denied by Pakistan. ${ }^{27}$ In light of those conclusions, it is no surprise that the Washington Post reported CIA and U.S. military officials as saying that they "now withhold intelligence about the suspected whereabouts of al-Qaeda commanders [in Pakistan] out of fear that the Pakistanis might tip them off., 28

${ }^{25}$ See Jones, supra note 11 , at 21.

${ }^{26}$ See CRS Report, supra note 1, at 27-28; Jones, supra note 11, at 57-58; Eric Schmitt \& Mark Mazzetti, Pakistan's Planned Accord With Militants Alarms U.S., N.Y. TIMES, Apr. 30, 2008, at A10; see also Ismail Khan \& Carlotta Gall, Pakistan Lets Tribal Chiefs Keep Control Along Border, N.Y. Times, Sept. 6, 2006, at A8.

${ }^{27}$ See Joby Warrick, U.S. Officials Pakistani Agents Helped Plan Kabul Bombing, WASH. Post, Aug. 1, 2008, at A1; CRS Report, supra note 1, at 25; Jones, supra note 11, at 54-57.

${ }^{28}$ See Craig Whitlock, In Hunt for Bin Laden, a New Approach, WASH. Post, Sept. 10, 2008, at A1. 
On the other hand, the Pakistani government's general indifference to militant attacks across the border into Afghanistan probably lies less in tacit support for those operations than in a simple belief that pursuing large-scale military operations in FATA that kill Pashtuns, trample prior agreements providing for FATA autonomy, and incur significant Pakistani army casualties would be extremely unpopular with the Pakistani population and ultimately ineffective in stopping cross-border attacks. Moreover, some Pakistani officials apparently wish to preserve the possibility of a "Taliban option," one that might prove useful for future relations in Afghanistan. ${ }^{29}$ Whatever the reason, by mid-2008 the New York Times was reporting that "Pakistani officials are making it increasingly clear that they have no interest in stopping crossborder attacks by militants into Afghanistan, prompting a new level of frustration from Americans who see the infiltration as a crucial strategic priority in the war in Afghanistan." ${ }^{30}$

\section{U.S. Cross-Border Operations into Pakistan}

U.S. cross-border operations into Pakistan to date have taken three forms: missile strikes from Predator drones; defensive actions in immediate response to a cross-border raid from Afghanistan; and covert missions by special operations forces against militant targets located deeper in Pakistan. Each should be considered separately when analyzing their legality under the jus ad bellum.

${ }^{29}$ See Nayak, supra note 3, at 305-06.

${ }^{30}$ Jane Perlez, Pakistan Defies U.S. On Halting Attacks, N.Y. TIMES, May 16, 2008, at A6. 
First, the United States has engaged in attacks against what are believed to be Al Qaeda and Taliban targets (such as training camps, compounds, or convoys) in Pakistan, using Hellfire missiles launched from unmanned Predator aircraft. At least some of those aircraft are reportedly kept at a secret base in Pakistan, not Afghanistan, such that these are not necessarily cross-border operations. ${ }^{31}$ Further, the Pakistani government apparently has tacitly agreed that these strikes may be undertaken without specific consent to each operation, so long as they target "foreign fighters" and not Pakistani Taliban, though the existence of that tacit consent is disputed. ${ }^{32}$ While the United States does not disclose its strikes, the Pakistani government asserted that three strikes occurred in 2007 while eleven were conducted from January to August of $2008,{ }^{33}$ with perhaps another dozen or more in September and October. ${ }^{34}$ The strikes reportedly have had some success, killing several senior Al Qaeda leaders. ${ }^{35}$ Yet they have also been blamed for the deaths of dozens of civilians in Pakistan, collateral casualties that have fueled resentment among Pakistanis toward the United States. If relations between the United States and Pakistan were to deteriorate, and Predator aircraft were no longer allowed to be launched from within Pakistan, then presumably such aircraft might be based in Afghanistan for the purpose of undertaking missions cross-border into Pakistan.

${ }^{31}$ See CRS Report, supra note 1, at 36; Joby Warrick \& Robin Wright, Unilateral Strike Called a Model for U.S. Operations in Pakistan, WASH. Post, Feb. 19, 2008, at A1.

${ }^{32}$ See CRS Report, supra note 1, at 36; Robin Wright \& Joby Warrick, U.S. Steps Up Unilateral Strikes in Pakistan, WASH. Post, Mar. 27, 2008, at A1.

${ }^{33}$ See Craig Whitlock, In Hunt for Bin Laden, a New Approach, WASH. Post, Sept. 10, 2008, at A1.

${ }^{34}$ See Officials Report Airstrike, WASH. Post, Oct. 27, 2008, at A10.

${ }^{35}$ See Saad Gul \& Katherine M. Royal, Burning the Barn to Roast the Pig?

Proportionatlity Concerns in the War on Terror and the Damadola Incident, 14 WILLAMETTE J. 
Second, while U.S. military forces engaged in military operations in Afghanistan are generally prohibited from crossing or firing into Afghanistan, their rules of engagement apparently allow them to do so as a matter of "hot pursuit" when engaging in self-defense. ${ }^{36}$ Hence, when U.S. forces come under attack from militants (either by fire artillery fire from Pakistan or by militant units who cross over the border from Pakistan), U.S. forces have responded forcibly against the militants both in Afghanistan and through pursuit of the militants back into Pakistan. For example, in June 2008, U.S. officials asserted that Taliban fighters from Pakistan crossed over the border into Afghanistan (Kunar Province) and attacked U.S. led forces with small caliber weapons and rocket propelled grenades. The U.S.-led forces returned fire, drove the militants back across the border, and then pursued them with U.S. air force fighterbombers and a B-1 bomber, which dropped twelve gravity bombs on them. Though U.S. forces apparently alerted Pakistani forces in advance about the intended air strike, Pakistani Frontier Corps personnel were present at a border checkpoint and eleven were killed by the bombs (as were several of the militants), resulting in a strong protest by the Pakistani government that the U.S. operation was "a gross violation of the international border."37

The determination that an attack from Pakistan against U.S. forces in Afghanistan has occurred or is occurring has proven somewhat elastic. Hence, in at least one instance, when U.S.

INT'L L. \& DisP. RESOL. 49, 51 (2006).

${ }^{36}$ See, e.g., Reza Sayah, Pakistan fury over U.S. 'hot pursuit' act, CNN, June 11, 2008, http://www.cnn.com/2008/WORLD/asiapcf/06/11/pakistan.troops.killed/index.html .

${ }^{37}$ See Carlotta Gall \& Eric Schmitt, Pakistan Angry as Strike by U.S. Kills 11 Soldiers, N.Y. TIMES, June 12, 2008, at A1; CRS Report, supra note 1, at 34-35. In at least one instance, Pakistani military forces may have fired warning shots to prevent U.S. troops from crossing the border into Pakistan. See Candace Rondeaux, Pakistan Allegedly Repulses U.S. Raid, WASH. 
forces received information that militants were on the move in Pakistan and heading toward U.S. forces in Afghanistan, U.S. forces preemptively attacked the militants even before they crossed the border, including striking a compound one mile within Pakistan with missiles. ${ }^{38}$

Third, U.S. cross-border operations now apparently include covert missions by a U.S. joint special operations forces task force ("JSOC," likely consisting of Navy SEALs and the Army's Delta Force ${ }^{39}$ ) in pursuit of targets in Pakistan's tribal areas - missions not undertaken in immediate response to a cross-border raid from Pakistan. Such missions reportedly were planned but not undertaken up until mid-2008, due to concerns about the likely success of such missions, the effect on relations with the government of Pakistan, and the risks attendant to special forces being killed or captured. ${ }^{40}$ In July 2008, however, President Bush reportedly issued secret orders for such operations to occur even in the absence of express and prior Pakistani government approval. According to the New York Times, which broke the story:

The new orders reflect concern about safe havens for Al Qaeda and the Taliban inside Pakistan, as well as an American view that Pakistan lacks the will and ability to combat militants. They also illustrate lingering distrust of the Pakistani military and intelligence agencies and a belief that some American operations have been compromised

Post, Sept. 16, 2008, at A12.

${ }^{38}$ See Ann Scott Tyson, Border Complicates War in Afghanistan, WASH. Post, Apr. 4, 2008, at A1.

${ }^{39}$ See Sean D. Naylor, Spec Ops Raids Into Pakistan Halted, NAVY Times, Sept. 29, 2008.

${ }^{40}$ See Craig Whitlock, In Hunt for Bin Laden, a New Approach, WASH. Post, Sept. 10, 2008, at A1. 
once Pakistanis were advised of the details. ${ }^{41}$

On September 3, 2008, the first operation occurred, involving U.S. Navy SEALs crossing the border on helicopters, supported by an AC-130 gunship, landing in Angor Adda (in the South Waziristan tribal agency), killing about two dozen suspected Al Qaeda fighters, and then returning to Afghanistan by helicopter. ${ }^{42}$ Pakistani authorities strongly objected to the operation and threatened, if such attacks continued, to cut off U.S. supply lines through Pakistan to U.S. forces in land-locked Afghanistan. ${ }^{43}$

III. Potential Legal Bases for U.S. Cross-Border Operations

Article 2(4) of the U.N. Charter provides that: "All members shall refrain in their international relations from the threat or use of force against the territorial integrity or political independence of any state, or in any other manner inconsistent with the Purposes of the United Nations." ${ }^{44}$ The three forms of cross-border (or, with respect to drone aircraft, potentially crossborder) operations noted in the prior section would likely be regarded as violations of Article 2(4) in the absence of some form of justification, for they entail military personnel or weapons

${ }^{41}$ See Eric Schmitt \& Mark Mazzetti, Bush Said to Give Orders Allowing Raids in Pakistan, N.Y. TIMES, Sept. 10, 2008, at A1.

${ }^{42}$ Id.; Craig Whitlock, In Hunt for Bin Laden, a New Approach, WASH. Post, Sept. 10, 2008, at A1 (reporting that "U.S. commandos crossed from Afghanistan into Pakistan in helicopters and killed about 20 people in a suspected Taliban compound in South Waziristan."). The rules of engagement for special operations forces operating in Afghanistan are classified.

43 See Naylor, supra note 39 (quoting an unnamed U.S. government official that the raid was a "strategic miscalculation").

${ }^{44}$ U.N. Charter art. 2(4). 
entering Pakistani territory and inflicting considerable violence upon persons present in Pakistan and their property. There are, however, four potential bases for justifying these cross-border operations under international law: (A) consent by the Pakistani government; (B) authorization by the U.N. Security Council; (C) inherent self-defense against non-state actors operating from Pakistan; or (D) inherent self-defense against Pakistan itself. Each justification is briefly discussed in turn.

\section{A. U.S. Cross-Border Action Taken with the Consent of Pakistan}

To the extent that the government of Pakistan has consented to U.S. cross-border military operations from Afghanistan into Pakistan, that consent obviates any question about the legality of those operations under international law. Standard rules on state responsibility accept that conduct does not violate an obligation to a state if that state has consented to the conduct, ${ }^{45}$ and that view applies in the area of the jus ad bellum as well. ${ }^{46}$ While the legal justification for U.S. cross-border operations appears heavily reliant on Pakistani consent, the existence of such consent to the three forms of U.S. cross-border operations discussed above is not at all clear or may not prove enduring.

${ }^{45}$ See, e.g., International Law Commission, Articles on Responsibility of States for Internationally Wrongful Acts, art. 20, in Report of the International Law Commission, Fiftythird Session, U.N. Doc. A/56/10 (2001) ("Valid consent by a State to the commission of a given act by another State precludes the wrongfulness of that act in relation to the former State to the extent that the act remains within the limits of that consent.")

${ }^{46}$ See, e.g., Oscar Schachter, The Right of States to Use Armed Force, 82 MicH. L. REV. 1620, 1644-45 (1984) (seeing no violation of U.N. Charter Article 2(4) "when a foreign force is invited by the government to help put down an attempted coup or assist in restoring law and order"). 
Media reports, largely based on off-the-record comments by senior U.S. and Pakistani officials, indicate that Pakistan's civilian and military leadership are not prepared publicly to support U.S. cross-border operations into Pakistan. ${ }^{47}$ Yet that lack of public consent does not mean that Pakistani consent does not exist. Surveying the background to U.S. cross-border operations, the Washington Post has noted that although Pakistan "formally protests such actions as a violation of its sovereignty, the Pakistani government has generally looked the other way when the CIA conducted Predator missions or U.S. troops respond to cross-border attacks by the Taliban." ${ }^{48}$ There may be internal documents or communications from the Pakistani government that clarify such consent and, if so, the United States will be in a strong position to establish the legality of these operations in whatever venue is necessary, assuming such information can be made public. Certainly the Pakistani government's knowledge of Predator drones being based in Pakistan, and its knowledge that such aircraft are being used for missile strikes, presents a strong picture of tacit consent so long as such knowledge can be established. However, if the Pakistani government's consent is based solely on a belief that the Pakistani government is "looking the other way," then establishing consent may be difficult in the face of the various public protests about U.S. cross-border actions that have been made by Pakistan.

${ }^{47}$ See Ann Scott Tyson, Gates Is Pessimistic On Pakistani Support, WASH. Post, Sept. 24, 2008, at A16 (reporting testimony of Secretary of Defense Gates).

${ }^{48}$ See Craig Whitlock, In Hunt for Bin Laden, a New Approach, WASH. Post, Sept. 10, 2008, at A1; Eric Schmitt \& David E. Sanger, Pakistan Shift Could Curtail Drone Strikes, N.Y. TIMES, Feb. 22, 2008, at A1 (reporting that "American officials reached a quiet understanding with Pakistan's leader last month to intensify secret strikes against suspected terrorists by pilotless aircraft launched in Pakistan"). 
With respect to the more recent special operations missions, the New York Times reported that a "senior American official said that the Pakistani government had privately assented to the general concept of limited ground assaults by Special Operations forces against significant military targets, but that it did not approve each mission. ${ }^{, 49}$ Yet the public stance of the Pakistani government is that such operations are not permitted..$^{50}$ In the wake of the September 3, 2008, cross-border operation by U.S. Navy SEALs, and the adverse reaction of Pakistani army and public opinion to such raids, the Chief of the Pakistani Army, General Ashfaq Parvez, asserted: "There is no question of any agreement or understanding with the coalition forces whereby they are allowed to conduct operations on our side of the border." ${ }^{51}$

Confusion about the existence of consent stems in part from the fractured nature of the Pakistani government. ${ }^{52}$ The President of Pakistan, Asif Ali Zardari, is the official head of state, while Prime Minister Syed Yousaf Raza Gillani is the head of government. The President and his designees would normally be looked to for Pakistani consent to the use of force by another state in Pakistan. Under Pakistani law, the President appoints the Chief of the Army Staff, currently General Ashfaq Parvez Kayani, an individual that might be seen as deputized to provide consent on behalf of the President. Yet, at present, there is a considerable divide in views between President Zardari and the Army leadership, including over Pakistani consent to U.S. cross-border

${ }^{49}$ See Eric Schmitt \& Mark Mazzetti, Bush Said to Give Orders Allowing Raids in Pakistan, N.Y. TIMES, Sept. 11, 2008, at A1.

${ }^{50}$ See CRS Report, supra note 1, at 34 ("Permission for U.S.-led attacks on forces under the command of militant leaders . .. is not forthcoming to date ...).

${ }^{51}$ See Jane Perlez, Pakistan's Military Chief Criticizes U.S. Over a Raid, WASH. Post, Sept. 10, 2008, at A8.

${ }^{52}$ See generally Stephen PhiLip CoHen, The IdeA of PAKistan (2004). 
operations. ${ }^{53}$ The Army's disagreements with the civilian leadership are not simply bureaucratic maneuvers; on several occasions the army has overthrown the President and Prime Minister, most recently in October 1999 when the army deposed the elected Prime Minister, Nawaz Sharif, in a bloodless coup. ${ }^{54}$ Moreover, as indicated above, with the "Talibanization" of the western region, Pakistani sovereign power in the FATA is almost de minimis, suggesting a nascent insurgency that already contests Islamabad's authority in the west and that may ultimately contest it nationwide. Depending on how Pakistani politics unfold, discerning consent solely from the President may or may not reflect the true source of sovereign power in Pakistan.

Even if sovereign consent may be discerned, there are disadvantages to the United States in basing the jus ad bellum legality of its operations solely on the consent of the Pakistani government. That consent, whether given explicitly or implicitly, may be withdrawn at any time, unless it is expressed as a legally binding commitment for a specified period of time. With the changes in leadership within Pakistan in recent years, consent from the government cannot be relied upon as steadfast. Moreover, consent may always be predicated on certain requirements, such as prior notification of a given action to the Pakistan, which may be difficult for timesensitive operations or where concerns exist about maintaining confidentiality. Since the host government's consent only establishes the legality of action taken within the scope of the consent, the any U.S. operations taken outside that scope will implicate Article 2(4). For example, if it is true that Predator drone strikes are only authorized for attacks against Al Qaeda

${ }^{53}$ See, e.g., id. (recounting apparent disagreement between President Zardari and General Kayani over the permissibility of the September 3, 2008, cross-border special forces operation).

${ }^{54}$ See, e.g., OWEn Bennett Jones, Pakistan: Eye of the StORM 34-55 (2003). 
or foreign fighters, then pursuit of such strikes against Taliban could be regarded as a violation of the jus ad bellum.

Finally, while consent is a valid justification when it is received from a de jure government fully in control of its territory, it might become invalid if that government no longer controls or only partially controls its territory. Traditional jus ad bellum doctrine regards support for a government as permissible until such point as an internal insurgency has risen to the level of being a co-belligerent with the government, at which point arguably the government is no longer "in a position to invite assistance in the name of the state." "Talibanization" of the western provinces of Pakistan continues apace, and spreads throughout Pakistan, at some point the ability of the de jure government to consent to U.S. cross-border operations under international law may be regarded in the international community as insufficient to support the legality of those operations. ${ }^{56}$

In short, consent of the Pakistani government is a strong legal justification for the use of U.S. Predator aircraft in Pakistan, so long as Pakistan continues to allow them to be launched

\footnotetext{
${ }^{55}$ Wolfgang Friedmann, The Changing Structure of InTERnAtional LAW 266 (1964).

${ }^{56}$ By way of example, some states expressed concern about Ethiopia's intervention in Somalia in 2006 for the purpose of suppressing the Union of Islamic Courts (UIC). While the intervention was conducted the request of the Somali Transitional Government, which had been established with the backing of the United Nations, the African Union, and the Arab League, the transitional government controlled only a small portion of southern Somalia at the time of the intervention, while the UIC controlled the Somali capital and much of the rest of the country. "In such a fragile situation and in a crisis mainly of an internal nature, military intervention by invitation may be very controversial indeed ...." Zeray W. Yihdego, Ethiopia's Military Action Against the Union of Islamic Courts and Others in Somalia: Some Legal Implications, 56 INT'L
} 
from a Pakistani base. U.S. cross-border operations, however, can only rely upon this justification if authoritative decision-makers in Pakistan have formally consented to the type of operation at issue, and so long as that consent remains intact. The facts publicly available suggest Pakistani tolerance of, but not necessarily formal consent to, U.S. cross-border operations undertaken in immediate response to attacks by militants staged from Pakistan. Even for these operations, Pakistan appears to expect notification and avoidance of actions that could harm Pakistani forces or civilians. By contrast, Pakistan publicly appears to have rejected cross-border operations by U.S. special forces undertaken deeper in Pakistani territory and not in response to an immediate raid from Pakistan. Overall, given the potential difficulty in proving the existence Pakistani consent to U.S. cross-border operations, and the possibility of such consent ending, other justifications for U.S. cross-border operations should be considered as well.

\section{B. U.S. Cross-Border Action Authorized by the U.N. Security Council}

Assuming that Pakistani government consent cannot be found in support of all or some of U.S. cross-border operations, an alternative basis for legality might be pursued in the form of Security Council authorization. When acting under U.N. Charter Chapter VII, the Security Council is empowered to decide upon measures necessary for maintaining or restoring peace and security, including measures that are forcible in nature. ${ }^{57}$ The Security Council has adopted several resolutions relating to Afghanistan in the aftermath of the attacks of $9 / 11$, but none of those resolutions appears to authorize U.S. cross-border operations into Pakistan.

COMP. L.Q. 666 (2008). 
Prior to the overthrow of the de facto Afghan government of the Taliban, the Security Council adopted two resolutions that affirmed, in the context of the $9 / 11$ attacks, the inherent right of individual and collective self-defense and the need "to combat by all means" the "threats to international peace and security caused by terrorist acts. ${ }^{, 58}$ These resolutions did not constitute a Chapter VII authorization from the Security Council to use force; rather, they were a confirmation of an inherent right of self-defense that preceded and was preserved through passage of the resolutions. ${ }^{59}$ The next sub-section considers whether U.S. cross-border operations into Pakistan can be justified on the basis of individual or collective self-defense.

After the de facto Taliban government was overthrown in late 2001, the United Nations facilitated negotiations in Bonn, Germany to establish a framework and timeline for the establishment of new Afghan political institutions. Moreover, Annex 1 of the Bonn Agreement provided that "the participants request the assistance of the international community in helping the new Afghan authorities in the establishment and training of new Afghan security and armed forces," and requested "the early deployment to Afghanistan of a United Nations mandated force. ${ }^{, 60}$ In Resolution 1386, the Security Council endorsed the Bonn Agreement and authorized

${ }^{57}$ See U.N. Charter arts. $39 \& 42$.

${ }^{58}$ S.C. Res. 1368, pmbl., U.N. Doc. S/RES/1368 (Sept. 12, 2001); S.C. Res. 1373, pmbl., U.N. Doc. S/RES/1373 (Sept. 28, 2001).

${ }^{59}$ See Michael J. Matheson, Council Unbound: Error! Main Document

ONLY.The Growth OF UN DECISION MAKING ON CONFLICT AND POSTCONFLICT ISSUES AFTER THE COLD WAR 157 (2006).

${ }^{60}$ Agreement on Provisional Arrangements in Afghanistan Pending the Re-establishment of Permanent Government Institutions, annex 1, Dec. 5, 2001, printed inLetter dated 5 December 2001 from the Secretary-General addressed to the President of the Security Council, U.N. Doc. 
the establishment of the International Security Assistance Force (ISAF) "to assist the Afghan Interim Authority in the maintenance of security in Kabul and its surrounding areas, so that the Afghan Interim Authority as well as the personnel of the United Nations can operate in a secure environment."61 The resolution also called upon "Member States participating in the International Security Assistance Force to provide assistance to help the Afghan Interim Authority in the establishment and training of new Afghan security and armed forces." ${ }^{\text {, }}$ Shortly thereafter, the interim Afghan government concluded a bilateral agreement with ISAF concerning the size of the deployment and the tasks it would undertake. ${ }^{63}$ In 2002 , the Security Council adopted Resolution 1413, authorizing "Member States participating in the International Security Assistance Force to take all necessary measures to fulfill the mandate of the International Security Assistance Force." ${ }^{64}$ Subsequent resolutions have extended ISAF's mandate temporally ${ }^{65}$ and geographically, such as allowing ISAF:

to support the Afghan Transitional Authority and its successors in the maintenance of security in areas of Afghanistan outside of Kabul and its environs, so that the Afghan

$\mathrm{S} / 2001 / 1154$ (2001).

${ }^{61}$ S.C. Res. 1386, ๆ 1, U.N. Doc. S/RES/1368 (Dec. 20, 2001).

${ }^{62} \mathrm{Id}$. at 10. The Security Council also subsequently created a very modest U.N. Assistance Mission in Afghanistan (UNAMA) of less than 2,000 persons (mostly Afghan nationals) charged with assisting the Afghan government Error! Main Document Only.in rebuilding the country and strengthening the foundations of peace and constitutional democracy.

${ }^{63}$ Military Technical Agreement, Afghan.-ISAF, Jan. 4, 2002, http://www.operations.mod.uk/isafmta.pdf. After NATO assumed control of ISAF, a further bilateral agreement was concluded in between NATO and the Afghan government on December 9, 2003.

${ }^{64}$ S.C. Res. 1413, ๆ 2, U.N. Doc. S/RES/1413 (May 23, 2002).

${ }^{65}$ See S.C. Res. 1833, U.N. Doc. S/RES/1833 (Sept. 22, 2008) (extending ISAF's

mandate for a period of twelve months beginning October, 13, 2008). 
Authorities as well as the personnel of the United Nations and other international civilian personnel engaged, in particular, in reconstruction and humanitarian efforts, can operate in a secure environment, and to provide security assistance for the performance of other tasks in support of the Bonn Agreement. ${ }^{66}$

From these instruments, it is apparent that ISAF is a multinational security force authorized by the U.N. Security Council under Chapter VII of the U.N. Charter. ISAF is not a U.N. force in the sense of being funded by, and under the command-and-control of, the United Nations; rather, it is a coalition of self-funding states authorized by the Security Council to engage in specified tasks in Afghanistan. Though the Security Council theoretically could authorize ISAF to engage in cross-border operations into Pakistan, no such authorization exists in any of the Security Council resolutions either expressly or by implication. Indeed, while ISAF sees its mission as including efforts to defeat the threat of insurgency in Afghanistan, NATO's 2005 Operational Plan, as revised, provides that ISAF's mission is the stabilization of Afghanistan, not counter-terrorism. ${ }^{67}$

U.S. cross-border operations are not undertaken through ISAF. Rather, such operations occur as a part of the multi-national coalition of states present in Afghanistan for Operation Enduring Freedom (OEF). U.S. forces in Afghanistan for OEF are deployed as the Combined

${ }^{66}$ S.C. Res. 1510, ๆ 1, U.N. Doc. S/RES/1510 (Oct. 13, 2003).

${ }^{67}$ See NATO Press Release, Revised Operational Plan for NATO's Expanded Mission in Afghanistan (updated July 4, 2007), at

http://www.nato.int/issues/afghanistan_stage3/index.html; see also MATHESON, supra note 59, at 116. 
Joint Task Force-82 (CJTF-82), which is based in Bagram Air Base. That task force reports to the U.S.-led Combined Forces Command-Afghanistan (CFC-A), which is based in Kabul. The CJTF-82 operates and supervises a Combined Joint Special Operations Task Force-Afghanistan (CJSOTF-A), which consists of special operations forces. Yet there is also reportedly an "Other Coalition Forces" (OCF) unit of special operations forces, which does not report to CJTF-82. This latter, more secretive unit may be the one responsible for the covert U.S. cross-border missions into Pakistan.

In any event, all of these U.S. forces deployed for OEF are separate from the U.S. forces deployed in support of the U.N.-mandated and NATO-led ISAF which, as discussed above, is focused on providing security in Kabul and its surrounding areas for the Afghan government, and assisting the government in the establishment and training of Afghan security and armed forces. ISAF and OEF have completely separate mandates and missions, with ISAF focusing on a stabilization and security mission, while OEF focuses on the counter-terrorism mission. None of the Security Council resolutions discussed above relate to OEF and hence cannot serve as a basis for a Security Council mandate for the United States to engage in cross-border operations into Pakistan.

C. U.S. Cross-Border Action Taken in Self-Defense against Non-State Actors

A third basis for maintaining that U.S. cross-border operations into Pakistan are permissible under the jus ad bellum relies upon the United States' inherent right of self-defense 
or its right to engage in collective self-defense at the request of Afghanistan. Article 51 of the U.N. Charter indicates that the prohibition on the use of force embedded in Article 2(4) may be justified when acting in self-defense, since: "Nothing in the present Charter shall impair the inherent right of individual or collective self-defense if an armed attack occurs against a Member of the United Nations, until the Security Council has taken the measures necessary to maintain international peace and security."

In considering this basis, there are several key and perhaps troubling questions that arise: What was the preceding use of force against which the United States is defending? Does that preceding use of force rise to the level of an "armed attack" within the meaning of U.N. Charter Article 51? Can the United States invoke Article 51 when defending against the conduct of a non-state actor? Are the U.S. cross-border actions necessary and proportionate defensive responses? Each question is discussed in turn.

What was the preceding use of force against which the United States is defending? There are two candidates for the preceding uses of force to which the United States is responding in self-defense. First, the United States might be seen as today still defending against Al Qaeda's attacks of 9/11 (as well as perhaps other actions taken by Al Qaeda globally against the United States, such as the 1998 bombing of U.S. embassies in Tanzania and Kenya and the 2000 attack on the USS Cole in Yemen). If the initial U.S. invasion of Afghanistan was a permissible act of self-defense against the perpetrators of 9/11, one designed to diminish or destroy Al Qaeda's

\footnotetext{
${ }^{68}$ U.N. Charter art. 51.
} 
network, then cross-border operations today might be seen as part of a continuous process to accomplish that objective, albeit years later. There has been no temporal interruption in the deployment of U.S. forces for this purpose, nor has there been a geographic interruption given that Al Qaeda elements fled toward and across the Pakistani border.

One complicating factor, however, arises from the use of cross-border operations to diminish or destroy the Taliban instead of Al Qaeda. Even at the time of 9/11, there were some doubts expressed about the right of the United States to defend against the $9 / 11$ attacks by using force for the purpose of ousting and destroying the Taliban. ${ }^{69}$ While selective attacks on the Taliban that were necessary to defend U.S. forces hunting down Al Qaeda elements post-9/11 were squarely within the notion of self-defending against Al Qaeda's 9/11 attacks, operations directed solely against the Taliban were seen as more problematic, since the Taliban was not directly involved in the $9 / 11$ attacks, in the sense of planning, funding, sending persons, or otherwise sponsoring those attacks.

An alternative preceding act triggering a right of U.S. self-defense are the more recent cross-border raids into Afghanistan by militants based in Pakistan (mostly Taliban, but with support from Al Qaeda and other foreign fighters) to strike at U.S. or coalition forces, or the government of Afghanistan. This approach does not emphasize the attacks of 9/11 but, rather, the contemporary cross-border operations that are harming coalition and Afghan interests in Afghanistan. So long as Afghanistan has consented to the presence of U.S. forces as a means of

${ }^{69}$ See, e.g., Jordan J. Paust, Use of Armed Force against Terrorists in Afghanistan, Iraq, 
assisting Afghanistan in defending against such attacks, U.S. actions fall within the scope of either individual or collective self-defense, though they should be notified to the U.N. Security Council in accordance with U.N. Charter Article 51. Afghan President Hamid Karzai himself has asserted Afghanistan's right to defend itself from such attacks by crossing the border into Pakistan and destroying "terrorist nests." ${ }^{70}$ Here, though, the complicating factor is the converse of that noted above; to the extent that the Taliban are principally responsible for such crossborder operations, then it is their conduct that may be seen as triggering a right of self-defense and it is their conduct against which defensive measures may be taken. Only to the extent that Al Qaeda is engaged in the cross-border attacks into Afghanistan can U.S. defensive responses against those attacks target Al Qaeda elements.

The upshot is that the preceding acts at issue may be a hybrid. U.S. cross border actions against Al Qaeda in the form of covert special forces missions (as well as Predator attacks when launched from Afghanistan) are probably best viewed as a continuing defensive response to the attacks of 9/11, whereas actions against Taliban and other militants infiltrating Afghanistan are best viewed as a defensive response against attacks occurring today on coalition forces in Afghanistan, as well as the Afghan government.

Do those preceding uses of force rise to the level of an "armed attack" within the meaning of U.N. Charter Article 51? Article 51, by its terms, preserves a pre-existing right of self defense "if an armed attack occurs." Scholars and states differ over whether such language

and Beyond, 35 CORNELL INT'L L.J. 533, 540-43 (2002). 
necessarily requires that an "armed attack" occur before the resort to self-defense, ${ }^{71}$ but governments typically argue that such an attack has occurred whenever they resort to selfdefense. $^{72}$ As such, a key question is whether the preceding actions that justify U.S. cross-border operations rise to the level of being an "armed attack" within the meaning of Article 51 . In the case concerning Military and Paramilitary Activities in and against Nicaragua (Nicaragua $v$. United States of America), the International Court of Justice provided some guidance on this point. On the one hand, a state's deployment of regular armed forces across a border, or the sending by a state of "armed bands, groups, irregulars or mercenaries which carry out acts of armed force," can constitute an armed attack; on the other hand, a state's "assistance to rebels in the form of the provision of weapons or logistical or other support" does not constitute an armed attack. $^{73}$ Hence, there is a sliding scale by which one assesses the level of intrusiveness and gravity of the act at issue to determine whether it rises to a level of "armed attack" that triggers a right of self-defense under Article 51.

With respect to the preceding act of Al Qaeda's conduct on 9/11, there should be little doubt that such coercion constitutes an "armed attack," given the scale of destruction and loss of

${ }^{70}$ CRS Report, supra note 1 , at 22.

${ }^{71}$ See, e.g., PreEMPtion: Military Action AND Moral JustificAtion (Henry Shue \& David Rodin eds., 2007); W. Michael Reisman \& Andrea Armstrong, The Past and Future of the Claim of Preemptive Self-Defense, 100 AM. J. INT'L L. 525, 525-26, 547-48 (2006) (finding that "the International Court of Justice and most international lawyers have steadfastly insisted on the strict application of the Charter regime" and that "[v]ery few of the more recent statements [of governments] seem to contemplate or claim a right to direct preemptive attacks against other states.").

72 See, e.g., Christine Gray, InTERnAtional LAW AND the Use of ForCE 130 (2d ed. 2004).

${ }^{73}$ Military and Paramilitary Activities (Nicar. v. U.S.), 1986 I.C.J. 14, 103-04 (June 27). 
life that occurred, as well as the reactions of the United States and relevant international organizations, all of which characterized the conduct as attacks triggering a right of selfdefense. $^{74}$

With respect to the preceding act of Taliban cross-border operations into Afghanistan, the gravity of those actions to date are of a much different character, in terms of the loss of life and destruction. Nevertheless, as indicated previously, the attacks are occurring at a rate of from twenty a month in March 2007 to fifty-three a month in April 2008, causing considerable injury and deaths to Afghans and the coalition forces that are in Afghanistan with Afghan consent. While any given cross-border raid into Afghanistan by militants from Pakistan might be said to fall below the threshold of an armed attack, and instead constitute merely a "frontier incident,"75 the cumulative effect of all these cross-border attacks by militants would likely be seen as constituting an "armed attack" within the meaning of Article 51.

Can the United States invoke Article 51 when defending against the conduct of a nonstate actor? Article 2(4) prohibits uses of force by one state against another state. Article 51 is less clear in speaking solely to conduct between two states, since its language simply speaks of a U.N. member's self-defense against an armed attack, without indicating whether it is a state that must be undertaking that attack. Even so, it might be argued that the Charter was designed solely to speak to rights and obligations as between states, and any act of self-defense must be in

${ }^{74}$ See Sean D. Murphy, Terrorism and the Concept of "Armed Attack" in Article 51 of the U.N. Charter, 43 HARV. INT'L L.J. 41, 45-51 (2002).

${ }^{75}$ Military and Paramilitary Activities, supra note 73, at para. 195. 
response to an armed attack committed by or attributable to another state. ${ }^{76}$ In the Military and Paramilitary Activities case, the International Court of Justice regarded attribution of non-state actor conduct to a state as the critical factor when weighing the permissibility of defensive action against that state, but did not directly address the issue of defensive action against the non-state actor itself. ${ }^{77}$ However, in the Advisory Opinion on the Israeli Wall, the Court—without much analysis - rejected Israel's claim that it was acting in self-defense against attacks by terrorist groups. The Court opined that Israel could not be acting in self-defense under Article 51 because (1) Israel had not claimed that the terrorist attacks at issue were imputable to a foreign state and (2) those attacks were not transnational in nature, having occurred wholly within territory occupied by Israel. ${ }^{78}$

If the advisory opinion is correctly interpreting the jus ad bellum, then it may not be possible to engage in Article 51 self-defense against a non-state actor; rather, self-defense is reserved for actions against another state, perhaps in situations where the acts of the non-state actor have been imputed to that other state. The Court's opinion, however, has been subjected to considerable criticism, much of which notes the fact that the global community (including the Security Council, NATO, and the OAS) appears to have regarded the attacks by Al Qaeda of

${ }^{76}$ See Eric Myjer \& Nigel White, The Twin Towers Attack: An Unlimited Right to SelfDefence, 7 J. CONFLICT \& SEC. 1, 7(2002) (arguing that "the categorization of the terrorist attacks on New York and Washington as an 'armed attack' within the meaning of article 51 is problematic to say the least. ... Self-defense, traditionally speaking, applied to an armed response to an attack by a state.").

${ }_{78}^{77}$. at 83-86, 119.

${ }^{78}$ Legal Consequences of the Construction of a Wall in the Occupied Palestinian Territory, Advisory Opinion, 2004 I.C.J. 136, 194 (July 9). 
9/11 as justifying a response in self-defense. ${ }^{79}$ Such criticisms may explain a possible retreat by the Court in its 2005 case concerning Armed Activities on the Territory of the Congo. In that case, rather than repeat its legal position from the advisory opinion, the Court stated that, given the facts at issue in the case, there was "no need to respond to the contentions of the Parties as to whether and under what conditions contemporary international law provides for a right of selfdefense against large-scale attacks by irregular forces. ${ }^{" 80}$ Both Judges Kooijmans and Simma stated in separate opinions that, if the Court still views Article 51 as restricted to self-defense only against an attack by another state, then the Court is out-of-step with both the Security Council and state practice. ${ }^{81}$

While this area of the law remains somewhat uncertain, the dominant trend in contemporary interstate relations seems to favor the view that states accept or at least tolerate acts of self-defense against a non-state actor. Turkey has engaged in various cross-border operations against the Kurdish separatist guerilla organization known as the Kurdistan Workers'

${ }^{79}$ See, e.g., Sean D. Murphy, Self-Defense and the Israeli Wall Advisory Opinion: An Ipse Dixit from the ICJ?, 99 AM. J. INT'L L. 62 (2005); see also YORAM DINSTEIN, WAR, AGGRESSION, AND SELF-DEFENCE 192 (3d ed. 2001) (stating that "for an armed attack to justify counter-measures of self-defense under Article 51, it need not be committed by another State"); Rein MError! Main Document Only.üllerson, Jus ad Bellum and International Terrorism, 79 NAVAl War College InT'L L. STUdies 75, 107, 109 (2003) (finding that “terrorism belongs to the domain of jus ad bellum as terrorist attacks may constitute a specific, non-traditional . . . form of an armed attack that gives rise to the right of self-defense . .." and "the right to selfdefense today includes measures undertaken against non-state entities").

${ }^{80}$ Armed Activities on the Territory of the Congo (Congo v. Uganda), 2005 I.C.J. 168, 223 (Dec. 19).

${ }^{81} I d$., Separate Opinion of Judge Kooijmans, para. 28; id., Separate Opinion of Judge Simma, para. 11. 
Party (or PKK), ${ }^{82}$ without being condemned by the Security Council, General Assembly, or International Court. In early 2008, Colombian military forces bombed and crossed into Ecuador to attack guerrillas of the Revolutionary Armed Forces of Colombia (FARC), which is regarded by Colombia as a terrorist and drug-trafficking organization. Again, none of the principal organs of the United Nations criticized the action; while the Organization of American States adopted a resolution declaring the Colombian raid to be a violation of Ecuador's sovereignty, the OAS stopped short of expressly condemning Colombia. ${ }^{83}$ Israel in the summer of 2006 sent military forces into, and bombed portions of, southern Lebanon in an effort to strike at the Hezbollah movement, which has operated out of Lebanon to attack and kill Israeli nationals. ${ }^{84}$ Similarly, in early 2008, Israel launched a major military ground operation, as well as air strikes, against Hamas fighters in the Gaza Strip. ${ }^{85}$ In neither instance did the principal U.N. organs declare the conduct unlawful self-defense. The United States undertook an air strike inside Syria in October 2008 reportedly to stem the flow of foreign fighters and weapons from that country into Iraq. ${ }^{86}$ As is the case for most customary law on the jus ad bellum norms, it is not possible to demonstrate through widespread and systematic state practice that the concept of self-defense

${ }^{82}$ See, e.g., Alissa J. Rubin \& Sabrina Tavernise, Turkish Planes Strike Iraqi Kurdistan, N.Y. Times, Feb. 5, 2008; Sabrina Tavernise \& Richard A. Oppel Jr., After 8 Days, Turkey Pulls Its Troops Out of Iraq, N.Y. Times, Mar. 1, 2008, at A8.

${ }^{83}$ See Org. Am. States, Convocation of the Meeting of Consultation of Ministers of Foreign Affairs and Appointment of a Commission, CP/Res. 930 (1632/08) (Mar. 5, 2008).

${ }^{84}$ See Andreas Zimmerman, The Second Lebanon War: Jus ad Bellum, Jus in Bello and the Issue of Proportionality, 11 MAX PLANCK YRBK. U.N. 99 (2007); Human Rights Watch, Civilians under Assault: Hezbollah's Rocket Attacks on Israel in the 2006 War (Aug. 29, 2007), http://hrw.org/reports/2007/iopt0807/.

${ }^{85}$ See Griff Witte, 60 Gazans Killed in Incursion By Israel, WASH. PosT, Mar. 2, 2008, at A1.

${ }^{86}$ See Ernesto Londono, U.S. Airstrike Allegedly Kills 8 Inside Syria, WASH. Post, Oct. 27, 2008, at A9. 
embraces action against non-state actors, but the better view appears to be that it does.

Are the U.S. cross-border actions necessary and proportionate defensive responses? Although Article 51 of the U.N. Charter does not expressly require that self-defense be undertaken only as necessary and proportionate to the threat faced, those constraints present in customary international law on the use of force have been deemed applicable to the post-Charter jus ad bellum. As the International Court of Justice has stated:

The submission of the exercise of the right of self-defence to the conditions of necessity and proportionality is a rule of customary international law. As the Court stated in the case concerning Military and Paramilitary Activities in and against Nicaragua (Nicaragua v. United States of America), there is a "specific rule whereby self-defence would warrant only measures which are proportional to the armed attack and necessary to respond to it, a rule well established in customary international law" (I.C.J. Reports 1986, p. 94, para. 176). This dual condition applies equally to Article 51 of the Charter, whatever the means of force employed. ${ }^{87}$

In considering whether force is "necessary," the International Court of Justice and scholars typically first consider whether there are peaceful alternatives to self-defense, such as pursuing available diplomatic avenues. ${ }^{88}$ This might entail determining whether the attacker has 245 (July 8).

${ }^{87}$ Legality of the Threat or Use of Nuclear Weapons, Advisory Opinion, 1996 I.C.J. 226, 88 See, e.g., Yoram Dinstein, War, AgGression And SElf-Defence 237 (4 $4^{\text {th }}$ ed. 2005). 
been asked to desist from further attacks and to make reparation for injuries it has caused. Assuming that no reasonable alternative means exist, the concept of "necessity" focuses on the nature of the target pursued by the defender; where the target is the source (or one of the sources) of the threat to the defender, it is considered necessary defense to attack that target. "Necessity" does not require a defender to limit itself to actions that merely repel an initial attack; a state may use force in self-defense to remove a continuing threat to future security, ${ }^{89}$ such as pursuing action against Japan in the 1940s until its militarist regime has capitulated. An example of a lack of necessity may be seen in the International Court of Justice's Oil Platforms case, where the Court found that the United States did not complain to Iran about the military activities allegedly undertaken from the platforms, nor proved that the platforms were the source of the threat to the United States in the Gulf such that attacking them was necessary for eliminating that threat. ${ }^{90}$

"Proportionality" does not require that the force be a mirror image of the initial attack, nor that the defensive actions be restricted to the particular geographic location in which the initial attack occurred. Rather than focus on the form, substance, or strength of the initial attack, proportionality calls for assessing the result sought for eliminating that threat and the means being used to achieve that result. ${ }^{91}$ As suggested by Professor Roberto Ago, a rapporteur for the International Law Commission on the rules of state responsibility and later judge on the

89 See Judith GARDAm, NeCESSITy, Proportionality AND THE USE OF ForCE By STATES 4-8 (2004).

90 See Oil Platforms (Iran v. U.S.), 2003 I.C.J. 161, 196-98 (Nov. 6).

91 See GARDAM, supra note 89, at 8-19; see also Enzo Cannizzaro, The Role of Proportionality in the Law of Counter-Measures, 12 EUR. J. INT'L L. 889, 892 (2001) (finding that "even responses greatly exceeding the magnitude of the original breach and extrinsically unconnected therewith, could nevertheless be justified, if reasonably necessary to terminate it"). 
International Court of Justice, "in the case of action taken for the specific purpose of halting and repelling an armed attack, this does not mean that the action should be more or less commensurate with the attack. Its lawfulness cannot be measured except by its capacity for achieving the desired result." $" 92$ Such reasoning is reflected in the national military manuals adopted by many states; for instance, the U.S. Commander's Handbook on the Law of Naval Operations indicates that proportionality imposes a "requirement that the use of force be in all circumstances limited in intensity, duration and scope to that which is reasonably required to counter the attack or threat of attack and to ensure the continued safety of U.S. forces . ...,93

In the Oil Platforms case, the International Court signaled that, if it were proved that a shore-based missile had been launched by Iran against a U.S. flag vessel, a proportionate defensive response could include destroying an Iranian oil platform elsewhere in the Gulf, so long as the platform was shown to be engaged in assisting attacks on U.S. vessels in the Gulf. In other words, the Court found that a proportionate defensive response to a missile attack on a vessel was not limited to infliction of a missile attack in response, nor limited to the targeting of the facility from which the missile was launched. At the same time, the Court stated that, in a situation where the attack consists of the single mining of a ship (which was damaged but not sunk), a defensive response that destroys numerous vessels and aircraft of the attacker, as well as oil platforms, is disproportionate in scale to the threat. ${ }^{94}$ While one might argue about the Court's

92 Roberto Ago, Addendum to Eighth Report on State Responsibility, U.N. Doc. A/CN.4/318 \& Add. 104 (1979).

93 ANNOTATED SuPPLEMENT to THE COMMANDER's HANDBOOK ON THE LAW OF NAVAL OPERATIONS $\S 4.3 .2$ (A.R. Thomas \& J.C. Duncan eds., 1999).

${ }^{94} I d$. at $198-99$. 
treatment of the facts in that case, the thrust of the Court's dicta was to consider the nature of the threat being faced by the defender and whether the defensive conduct, by its nature and scale, was designed to eliminate that threat. Similarly, in Armed Activities on the Territory of the Congo, the Court indicated that the armed "taking of airports and towns many hundreds of kilometers from [the defending state's] border would not seem proportionate to the series of transborder attacks it claimed had given rise to the right of self-defence, nor to be necessary to that end."95

In considering the necessity and proportionality of U.S. cross-border operations against Pakistan, it is important to focus on the two preceding threats that appear to have prompted those operations: the attacks of $9 / 11$ and the more recent cross-border attacks from Pakistan into Afghanistan.

First, the Al Qaeda attacks of 9/11 serve as a preceding "armed attack" against the United States triggering a right of self-defense in the form of operations designed to remove the threat of Al Qaeda. Given that for years the United States had demanded that Al Qaeda desist from its activities and had sought extradition of Bin Laden and his lieutenants from Afghanistan, and given that the $9 / 11$ attacks were attributable to planning, training and funding emanating from Afghanistan, ${ }^{96}$ the defensive response taken against Al Qaeda personnel and camps in

95 Armed Activities on the Territory of the Congo, supra note 80, para 147.

96 See Gilles Dorronsoro, The Security Council and the Afghan Conflict, in THE UNITED NATIONS SECURITY COUNCIL AND WAR 459-61 (2008). 
Afghanistan is properly regarded as both necessary and proportionate. ${ }^{97}$

Yet most international observers or courts would likely find that the same is not true with respect to the ability of the United States to pursue defensive actions against Al Qaeda across a national boundary into Pakistan or any other country. Here the use of force in self-defense in response to the attacks of $9 / 11$ would likely be seen as both unnecessary and disproportionate, principally because Pakistan is a third country that in no sense harbored Al Qaeda elements at the time of 9/11. Such use of force is unnecessary given Pakistan's stated willingness to ally itself with the United States in its counter-terrorism efforts to strike at Al Qaeda. The United States no doubt disagrees and distrusts aspects of Pakistani policy on how best to engage in counterterrorism; yet those disagreements alone do not provide the legal justification for the United States to engage in unilateral uses of force in Pakistan. While working in conjunction with the Pakistani government is no doubt a difficult diplomatic challenge, most observers would likely say that it is an available avenue that makes the unilateral resort to force unnecessary. ${ }^{98}$

For similar reasons, the unilateral use of force to strike at Al Qaeda in Pakistan in response to the 9/11 attacks would be found disproportionate, in that the spatial and temporal

97 See MError! Main Document Only.üllerson, supra note 79, at 109 (finding that when "terrorists operate from the territory of a state and that state is unable or unwilling to end the terrorist acts, military action by other states directed at the terrorists within the state where the terror operations are originating from can be justified as a state of necessity") \& 113 (stating that "[o]nly the refusal of the Taliban regime to comply with US demands and their active defense of the Qaeda network led to the use of force in self-defense against both al Qaeda and the Taliban").

98 For policy recommendations on U.S. support to Pakistan for counter-insurgency operations, see Bergen, supra note 19, at 22. 
displacement of the threat of Al Qaeda to a different country introduces important competing values, to wit the territorial integrity and political independence of a country that did not knowingly support, sponsor, or tolerate Al Qaeda in the years preceding $9 / 11$. The violence that invariably accompanies unilateral uses of force, even those taken in self-defense, intrudes severely into the values of peace and stability to which Pakistan is entitled under the jus ad bellum, and does so without justification when the targeted state bears no responsibility for the initial armed attack against which defensive action is being deployed. ${ }^{99}$ Certainly if Osama Bin Laden were to turn up in a country such as Bulgaria or Tunisia, that circumstance would introduce multiple new variables for any proportionality analysis, such that the United States could not rely on the same analysis that justified intervening in Afghanistan in 2001. The same holds true for Pakistan, notwithstanding its existence as a neighbor to Afghanistan.

A final consideration is that, arguably, the threat to the United States from Al Qaeda itself has changed since 9/11; the Al Qaeda now in Pakistan is a considerably reduced and weakened entity, one forced to hide out in the hills, with difficulty in sustaining the same infrastructure it operated in Afghanistan. Some observers see Al Qaeda as having mutated into an almost headless hydra, such that the real threat of attacks to the United States now largely lies in numerous cells located worldwide. ${ }^{100}$ If so, then the elements of Al Qaeda present in

99 See Gregor Wettberg, The International Legality of SELF-Defense Against Non-STATE ACTORS 221 (2007).

100 See, e.g., Lieutenant General Michael D. Maples, U.S. Army Director, Defense Intelligence Agency, Current and Projected National Security Threats to the United States, Statement for the Record before the Senate Armed Services Committee, at 8 (Feb. 27, 2007), at http://armed-services.senate.gov/statemnt/2007/February/Maples\%2002-27-07.pdf ("In 2006, alQaida remained a loose network, broadly defined by the strategic objective of re-establishing 
Afghanistan, including Osama Bin Laden, remain dangerous, but may not be seen as operationally threatening the United States in the same manner as they did in 2001. As such, the defensive action that may be taken against those elements, in order to be proportionate, could be viewed as of a lesser magnitude than what was regarded as permissible in the immediate aftermath of 9/11. Not all analysts, however, see the threat of Al Qaeda as having changed so significantly since 9/11. While there may be "a low-level probability that al Qaeda will be able to attack the U.S. in the next five years," Al Qaeda even based along the Afghan-Pakistan border is still able to train personnel for and direct attacks abroad, such as the July 2005 London bombings, the foiled August 2006 plot in the United Kingdom to blow up U.S. airliners with liquid explosives, and Al Qaeda attacks in Iraq. ${ }^{101}$

Could circumstances change in Pakistan that might generate a consensus favorable to the unilateral resort to armed force in Pakistan against Al Qaeda because the latter represents a broad threat to U.S. national security? Certainly if the same circumstances arose as existed at the time of $9 / 11$ - with a radical Islamic government in Islamabad, one hostile to the United States and with close connections to Al Qaeda, resulting in a major Al Qaeda attack on the United Statesthen the unilateral use of force in self-defense against Al Qaeda in Pakistan would likely be seen as justified, just as it was in Afghanistan in 2001. A more difficult question might be whether such force would be justified in the period prior to Al Qaeda in Pakistan's attack on the United States, perhaps due to highly credible information concerning an imminent attack. At present,

their version of an Islamic caliphate, and unified by a common ideology rooted in the violent rejection of Western influence, especially in traditionally Islamic countries.").

101 See, e.g., Bergen, supra note 19, at 4-6. 
however, Pakistan simply is not like Afghanistan under the Taliban in 2001, and it is hoped that with proper support from the United States and other allies, and avoidance of tactics that fuel militancy, Pakistan will not descend to that level.

The second type of preceding armed attack are the cross-border raids by militants from Pakistan, principally Taliban but with support from Al Qaeda, against U.S. and coalition forces and the Afghan government in Afghanistan. Here the jus ad bellum requirements of necessity and proportionality do not lend themselves to broad conclusions, but do provide guidance for analyzing confrontations as their arise along the border. For example, the necessity of U.S. forces reacting to incursions by militants from Afghanistan will turn in part on whether the United States has pursued and continues to pursue all avenues possible to obtain Pakistani government support for preventing such incursions. Responses by U.S. forces to militant incursions will be regarded as necessary if it is evident that Pakistani authorities are unwilling or unable to stem such incursions from their territory. Further, responses by U.S. forces that react to an actual raid by militants into Afghanistan likely will be regarded as more necessary than those that act to interdict anticipated incursions, given that there is always uncertainly as to whether the anticipated event will actually occur. Responses by U.S. forces that react to incursions by directly and immediately targeting those militants, using force of a comparable nature and scale, likely will be regarded as more proportionate than responses that target other militants in other places and times, using force of considerably greater magnitude, though even the latter can be proportionate if designed to remove the overall threat of cross-border incursions from Pakistan. 
A perhaps harder question concerns the necessity and proportionality of striking at $\mathrm{Al}$ Qaeda officials, camps, or convoys as a response to Al Qaeda's support for militant crossborder raids into Afghanistan. Such attacks are more removed temporally and spatially from the cross-border raids by militants. Yet if Al Qaeda is providing training and other support for such raids, and in some instances even commanding them, then most observers would likely regard it as proportionate to the threat posed to respond by attacking persons and entities behind-the-lines directly associated with the raids. The facts of Al Qaeda's association with these cross-border raids would have to be well-understood and the acts of self-defense by the United States against Al Qaeda, in order to be proportionate, would need to be designed to prevent that association. As for whether such actions are necessary, they are not necessary in the sense of providing immediate defense to U.S. forces in Afghanistan who are under attack, but they are necessary if it can be shown that, in the absence of such actions, the cross-border raids from Pakistan will not stop.

The distinction drawn here may seem meaningless, if it allows the United States to strike at Al Qaeda not for purposes of responding to $9 / 11$, but instead for purposes of responding to $\mathrm{Al}$ Qaeda's association with cross-border raids into Afghanistan. Yet the point is that while jus ad bellum requirements of proportionality and necessity do not preclude U.S. cross-border operations in response to raids by militants from Pakistan, nor from attacking Al Qaeda elements in support of those raids, those requirements will likely be regarded as conditioning the manner in which the U.S. operations may be conducted. Rather than testing the necessity and proportionality of U.S. operations as against the threat posed by Al Qaeda from its attacks of 
9/11, they must be tested against the threat posed by Al Qaeda in its association with the crossborder raids, which depending on the facts can lead to considerable differences in the scope and intensity of U.S. measures that may be undertaken.

D. U.S. Cross-Border Action Taken in Self-Defense against Pakistan

At present, the United States has not regarded Pakistan itself as posing a threat to the security of the United States, but this may change in the future. As discussed above, while the Pakistani government's relationship with militant actors in the western part of Taliban is obscure, it is reasonably clear that Pakistan's interests and objectives are not fully synchronized with those of the United States. Though Pakistani officials seem to have no particular sympathy for Al Qaeda, the same is not uniformly true with respect to Tehrik-e-Taliban Pakistan. Over time, Pakistan's tolerance if not support for Tehrik-e-Taliban Pakistan, may lead to some level of indirect support for Al Qaeda, which would place Pakistan at considerable odds with U.S. interests.

The jus ad bellum disfavors action taken in self-defense against a government that is simply associated with a malfeasant non-state actor. The lesson of the Nicaragua case is that when a state simply harbors or even funds a bad actor, and that bad actor engages in an act of extreme violence against another state, the first state is not viewed as itself having committed an armed attack against the attacked state. Rules of state responsibility on the attribution of conduct to a state would require the host state itself to order the bad actor to engage in the violent 
conduct, to empower the bad actor to act on the state's behalf, to endorse the violent conduct, or perhaps to fail to prevent the violent conduct knowing that it was about to happen and having the means to prevent it. ${ }^{102}$ As such, imputing the armed attacks of Al Qaeda or of the Taliban into armed attacks of Pakistan at present would be a significant leap, at least in the absence of far greater connections between the Pakistani government and those militants than is presently understood to exist.

\section{Conclusion}

To date, U.S. cross-border operations from Afghanistan into Pakistan have taken three forms: the use of Predator drones to target Al Qaeda fighters (although such drones may be launched solely from within Pakistan); the "hot pursuit" of militants who engaged in raids from Pakistan against U.S. and allied forces in Afghanistan, as well as the Afghan government; and the deployment of special operations forces into Pakistan as a means of striking at Al Qaeda.

These types of cross-border operations clearly implicate the jus ad bellum, in that they entail one state projecting highly coercive military force into another state. Arguably Pakistan

102 See International Law Commission, Articles on Responsibility of States for Internationally Wrongful Acts, art. 20, in Report of the International Law Commission, Fiftythird Session, U.N. Doc. A/56/10 (2001); MError! Main Document Only.üllerson, supra note 79, at 109 (indicating that "if the territorial state, which has itself been unable to prevent terrorists attacking other states or their nationals and interests, resists the victim-state (or its allies) in their efforts to eliminate the terrorists, it itself becomes an accomplice to the terrorist organization"); id. 113 (stating that "[o]nly the refusal of the Taliban regime to comply with US demands and their active defense of the Qaeda network led to the use of force in self-defense against both al Qaeda and the Taliban"). 
has consented to at least some of these types of cross-border operations, but that consent is poorly documented, suffers from the conflicting and diffuse sources of authority within the Pakistani government, and ultimately may not endure given the vicissitudes of Pakistani domestic politics. As such, though consent is a powerful and useful basis for supporting the legality of U.S. cross-border operations, other justifications should be considered as well.

Assuming Pakistani consent is lacking, other justifications for U.S. cross-border operations must be considered. The U.N. Security Council has on several occasions addressed the legality of foreign forces in Afghanistan. Yet the Security Council's Chapter VII resolutions are best seen as either authorizing the presence of a multinational force designed to stabilize Afghanistan (without having as its mission counter-terrorism operations, let alone operations outside Afghanistan), or simply recognizing the inherent right of self-defense of the United States and its allies. The inherent right of self-defense (individual and collective) does justify U.S. cross-border operations that respond to raids by militants from Pakistan into Afghanistan, so long as the U.S. operations remain necessary and proportionate to the threat of those raids, and so long as the Afghan government consents to the presence of U.S. forces. Such self-defense would also support unilateral uses of U.S. force against Al Qaeda in Pakistan, either in the form of covert operations by special forces units or the launching of Predators from Afghanistan to strike at targets in Pakistan, so long as it can be shown that those Al Qaeda targets are ones that are supporting the cross-border raids into Pakistan, and so long as Pakistan is unwilling or unable to prevent Al Qaeda's support for those raids. 
A broader right of self-defense against Al Qaeda targets in Pakistan based on the attacks of $9 / 11$, however, is far more problematic, since the requirements of necessity and proportionality likely preclude unilateral uses of force against a third state that was not implicated in those attacks. In general, the jus ad bellum recognizes important rights of a defending state to maintain its security against the violence of a non-state actor, but those values must coexist with the rights of other states to their own security, rights that are not lost simply because the remnants of a dangerous non-state actor turn up on their territory. While circumstances may change in the future that could justify unilateral uses of U.S. force against Pakistan for the broader threat Al Qaeda poses to the United States, the jus ad bellum at present requires the United States, when pursuing that objective, to cooperate with the government of Pakistan in finding and neutralizing Al Qaeda, not unilateral attacks through covert missions and missile strikes by the United States without Pakistani consent. 